\title{
Peran Dakwah Dalam Problematika Masa Remaja
}

\author{
Novita Sugiestian \\ Institut Agama Islam Negeri (IAIN) Parepare \\ e-mail: novitasugiestian@iainpare.ac.id
}

\begin{abstract}
Abstrak
Artikel ini berisi tentang bagaimana peranan dakwah dalam mengatasi problematika remaja di era modern saat ini, melihat angka kenakalan remaja yang sudah terbilang memprihatinkan. Ada beberapa metode yang digunakan dalam melalkukan pendekatan pada remaja untuk mengatasi problematikanya.

Dengan mengumpulkan dan menganalisis beberapa referensi hasil dari bagaimana peran dakwah dalam mengatasi promblematika remaja itu bukan hanya peran dakwah yang diutamakan tapi juga lingkungan sekitar yang akan menjadi penunjang membentuk karakter atau kegiatan yang mengarah ke hal yang positif bagi remaja. Dengan melakukan metode menggunakan sarana teknologi yang terbilang ramai digunakan dikalangan remaja ini membuat remaja juga bisa turun aktif dalam membagikan dakwah melalui media sosial.
\end{abstract}

Kata kunc : Dakwah, problematika remaja 


\section{PENDAHULUAN}

\section{Latar Belakang}

Manusia merupakan makhluk sosial yang selalu berinteraksi dengan sesamanya. Manusia tidak dapat hidup sendir. Sebagai makhluk sosial karena manusia menjalankan peranannya dengan menggunakan simbol untuk mengkomunikasikan pemikiran dan perasaanya. Dalam pembahasan kali ini saya akan mengkhususkan kepada remaja, dimana remaja merupakan generasi masa depan kita maka dari itu perkembangannya perlu diperhatikan karena mereka akan menjadi pemimpin baik itu dari suatu organisasi, kelompok, rumah tangga ataupun memimpin kewajiban yang lebih besar jika dibandingkan waktu mereka masih anak-anak.

Pada perkembangan remaja bukan hanya bentuk badan yang berubah tetapi juga psikologisnya. Proses perubahannya ini sering membuat remaja menjadi kebingungan terhadap dirinya sendiri. Karena terkadang ia akan merasa ia masih anak-anak tapi jika bersama orang dewasa maka remaja akan merasa telah dewasa. Hal ini yang akan membuat remaja kebingugan.

Pengaruh lingkungan menjadi salah satu terpenting bagi perkembangan remaja secara psikologis, baik itu lingkungan keluarga, lingkungan sekolah ataupunn lingkungan masyarakat, remaja. Semakin banyak faktor yang mempengaruhi remaja dalam membentuk kepribadiannya, semakin banyak pula penyimpangan yang akan ditimbulkan (Muhammad al-Zuhaili 2004: 147). Saat ini remaja menjadi pusat perhatian dan menjadi topik yang sering dibicarakan karena bisa dilihat fenomena kenakalan remaja yang sampai saat inikasusnya selalu bertambah hingga mencapai tingkat yang memprihatinkan seperti salah satu kasus yang terjadi baru-baru ini yaitu muncikari yang menjual anak di bawah umur.

Berdasarkan data statistik, dari 210-an juta penduduk Indonesia maka 80\% penduduknya menganut agama Islam sehingga apabila remaja diasuh dengan pengasuhan yang berlandaskan al-Qur'an dan hadist maka anak-anak yang dihasilkan pun akan dapat mempunyai identitas diri. Tetapi kenyataannya tindak kenakalan yang dilakukan oleh remaja cenderung meningkat meskipun remaja tersebut diasuh oleh orangtua yang beragama Islam. Padahal kenakalan remaja itu merupakan salah satu bentuk belum sempurnanya identitas diri.

Maka dengan memupuk terus pemahaman atau lingkungan yang baik bagi para remaja itu juga akan mempengaruhi biologis mereka, aura positif yang didapatkan dari sekitatnya juga akan mengalir kedirinya. Para muballig dalam berdakwah sebagai proses komunikasi religius dengan mad'u (masyarakat), perlu mendapat dukungan dari semua kalangan masyarakat Islam. Peningkatan pemahaman umat senantiasa diarahkan kepada pentingnya ukhuwah islamiyah, tentunya tidak terlepas dari semangat keagamaan bahwa sesama muslim adalah saudara.

\section{Metode Penelitian}

Metode yang digunakan yaitu metode deskriptif yang bertujuan untuk membuat deskriptif secara sistematif dengan mengumpulkan beberapa informasi dari berbagai referensi ilmiah (seperti jurnal, skripsi dan lain-lain) yang berkaitan dengan peran dakwah dalam mengatasi problematika remaja. 


\section{PEMBAHASAN}

\section{Pengertian Remaja}

Remaja Adolescen (Remaja) berasal dari bahas latin adalascare yang berarti "bertumbuh"sepanjang fase perkembangan ini, sejumlah masalah fisik, sosial dan psikologis bergabung untuk menciptakan karasteristik, perilaku dan kebutuhan yang unik. Menurut Zakiah Darajat bahwa masa remaja atau "adolescene" dapat diartikan sebagai suatu masa perkembangan transisi antara pada masa anak dan pada masa dewasa yang mana mencakup dari perubahan biologis, perubahan kognitif dan perubahan sosial - emosional.

Masa remaja merupakan masa dimana kita bukan anak-anak lagi tapi juga belum sepenuhnya diterima untuk masuk dalam golongan dewasa, menurut M Arifin setiap remaja mempunyai batasan usia remaja masing-masing, diIndonesia ditetapkan batas usia remaja itu dari umur 13 - 17 tahun baik bagi laki-laki maupun perempuan.

\section{Ciri - Ciri Remaja}

Ada beberapa ciri - ciri yang perlu kita ketahui mengenai masalah Remaja ini. Adapun beberapa ciri - ciri tersebut adalah sebagai berikut :

1. Sebuah peningkatan pada emosional yang mana terjadi dengan secara cepat.

2. Perubahan yang cukup cepat secara fisik yang mana juga dapat disertai dengan suatu kematangan pada seksual.

3. Suatu perubahan didalam hal yang mana menarik bagi dirinya dan juga pada hubungan dengan orang lain.

4. Suatu perubahan pada nilai, yang mana apa yang telah mereka anggap penting pada suatu masa kanak-kanak akan menjadi kurang penting sebab telah mendekati tingkat dewasa.

5. Pada kebanyakan remaja biasanya bersikap ambivalen didalam menghadapi sebuah perubahan yang dapat terjadi.

\section{Kondisi dan Kenakalan Remaja}

Di era aat ini sangat mudah jika kita ingin mencari kelompok yang memiliki hobby atau kegemaran yang sama dengan kita, dapat dilihat dari kondisi remaja saat ini kita bisa melihat banyak jenis kelompok remaja di sosial media maupun dilingkungan sekitar, mulai dari kelompok para gamers, kelompok pencinta alam, kelompok seni, dan masih banyak kelompok ataupun komunitas yang anggotanya banyak remaja.

Diusia remaja ini mereka sebenarnya masih memerlukan perlindungan, ataupun pengawasan dalam mengambil tindakan karena remaja itu cenderung peniru, dalam masa pencarian jati dirinya ini para remajasering kali meniru apa yang dilakukan dari orang yang ia sukai, yang mereka idolakan tanpa memperhatikan dimana ia berada sehingga terkadang tindakan atau perilaku yang ia tiru itu menyimpang dari keadaan masyarakat sekitar, peniru yang baik itu bukan hanya meniru apa yang ia lihat tapi juga menyaring sebelum ia terapkan dalam kehidupan.

Kenakalan remaja itu meliputi segala perilaku yang menyimpang dari normanorma hukum pidana yang dilakukan oleh remaja yang dapat merugikan diri sendiri ataupun lingkungan yang ada disekitarnya. Walaupun terkadang yang ada didalam 
pikiran para remaja itu ada beberapa yang mereka anggap tidak melakukan kesalahan tapi mereka hanya ingin mendapatkan perhatian, karena remaja juga cenderung suka mencari perhatian terhadap lingkungan ataupun lawan jenisnya dengan melakukan halhal baru, ataupun beberapa kenakalan yang bisa menarik perhatian masyarakat.

Padahal diusia remaja ini banyak hal positif yang bisa dilakukan untuk mendapatkan perhatian, misalnya dengan ikut organisasi di sekolah ataupun ikut organisasi kemasyarakatan yang bisa membuat anda bisa lebih dikenal, bisa juga dengan ikut pada kegiatan keagamaan ataupun dalam kegiatan sosial maupun mengikuti lombalomba yang sesui dengan bakat dan minat masing-masing.

Adapun masalah yang sering dirasakan para remaja :

1. Ketidak stabilan emosi

Masa remaja merupakan adalah usia yang paling dipenuhi dengan semangat yang sangat tinggi, tapi adakalanya semangat tinggi yang dimiliki oleh remaja itu mengarah ke arah yang negatif karena remaja merupakan peralihan dari masa anak - anak ke dewasa sehingga status remaja ini masih samar-samar baik bagi dirinya sendiri ataupun lingkungan sekitarnya. Karena semangat remaja in sangat tinggi dan emosi yang membara membuat mereka kadang tidak stabil karena pengendalian diri mereka belum sempurna.

2. Kurangnya Percaya Diri

Hal ini terjadi karena orang tua kurang memotivasi anak untuk menyalurkan apa yang dia minati. Sehingga anak merasa tidak percaya diri.

3. Memikirkan Masa Depan

Karena pemikiran remaja sudah menuju dewasa maka kecerdasan yang hampir matang itu menyebabkan remaja merasa bahwa dirinya sudah bisa memilih, dapat mengerti dan mampu berpikir. Maka diusia ini ada juga remaja yang sudah memikirkan bagaimana masa depannya, apa yang akan dilakukan.

4. Ketidak Mampuan untuk Melibatkan Diri

Pada masa ini, perhatiannya terhadap kedudukannya dalam masyarakat lingkungannya terutama di kalangan remaja, sangat besar. Tapi karena suatu kecenderungan untuk mengintelektualkan mengenai segala sesuatu dan berpikir ekonomis membuat remaja sulit untuk melibatkan diri dalam hubungan pribadi dan dalam lingkungan kemasyarakatan.

\section{Peran Dakwah dalam Kehidupan Remaja}

Secara etimologi (bahasa), dakwah berasal dari kata bahasa Arab dakwah, merupakan bentuk masdar dari kata kerja da'a, yad'u, da'wah, berarti seruan, ajakan, atau panggilan. Kata dakwah juga berarti doa (al-du'a), yakni harapan, permohonan kepada Allah SWT atau seruan (al-nida). Doa atau seruan pada sesuatu berarti dorongan atau ajakan untuk mencapai sesuatu itu (al-du'a ila al-syai' al-hatsts 'ala qasdihi) (Ma'arif, 2011:17).

Sedangkan dakwah secara terminologi (istilah), dakwah dipandang sebagai seruan dan ajakan kepada manusia menuju kebaikan, petunjuk, serta amar ma'ruf (perintah yang baik) dan nahi munkar (mencegah kemungkaran) untuk mendapatkan kebahagiaan dunia maupun akhirat (Halimi, 2008:32). 
Karena remaja umumnya sudah mulai berpikir kritis dan tidak akan menerima sesuatu yang tidak masuk akal maka dari itu penyampaian dakwah kepada remaja itu harus logis. Maksudnya itu berdakwah sesuai dengan apa yang terjadi dilingkungan sekitar agar remaja lebih mudah untuk mengerti dan menerima pesan yang disampaikan. Apalagi para remaja ini terbilang sangat cepat bosan dengan hal yang sudah sering mereka dengar, maka para da'i harus menyampaikan pesannya dengan cara yang baru, yang lebih menyenangkan dibanding sebelumnya, mungkin dengan menggunakan bahasa kekinian yang banyak dipakai pada kalangan remaja.

Lalu bagaimana peran dakwan untuk mengatasi kenakalan remaja agar setiap perbuatannya tidak menyimpang dari norma-norma yang ada? Dimulai dari liingkungan yang sehat, Pendekatan dalam menyampaikan dakwah pada remaja itu harus beda, karena para remaja sebenarnya memiliki semangat yang tinggi jika hal yang dilihat itu menarik, maka dengan menggunakan cara yang kekinian dan dikemas dengan cara yang lebih menarik maka remaja akan lebih tertarik untuk mendengarkannya.

Untuk menyampaikan dakwah yang bisa diterima oleh masyarakat khususnya remaja itu maka harus menggunakan beberapa metode yaitu :

a. Tanya jawab

Dengan melakukan tanya jawab maka da'i dan para remaja akan berkomunikasi secara langsung dan da'i akan membantu dalam mengatasi problematika remaja dengan ajaran-ajaran islam. Jika remaja sudah ingin bertanya maka itu artinya sudah ada ketertarikan atau rasa ingin tahu lebih dalam mengenai dakwah yang disampaikan.

b. Metode Diskusi

Diskusi merupakan pertemuan ilmiah untuk bertukar pikiran mengenai suatu masalah yang didalamnya terdapat moderator atau pemimpin dan peserta diskusi.

Dengan berduskusi para remaja juga dilatih untuk berpikir kritis dengan bertukar pikiran, dan jika mendiskusikan tentang agama maka remaja tidak akan merasa sendirian jika membahas masalah agama.

c. Dakwah dengan Contoh atau Keteladan

Karena remaja cenderung peniru maka metode ini sangat cocok bagi kalangan remaja, karena jika remaja mengitu teman atau orang terdekatnya dengan memberikan contoh bagi para remaja dalam melakukan kebaikan, remaja tersebut akan mencontohnya. Misalnya jika sedang berkumpul bersama remaja dan melihat ada orang dipinggir jalan yang sedang kesusahan dan salah satu orang diperkumpulan itu turut membantu orang tersebut maka hal itu bisa dikatakan dengan dakwah dengan contoh.

d. Metode Dakwah dengan Melibatkan Sarana Teknologi

Di era sekarang ini hampir semua remaja sudah mengenal teknologi dan bahkan sudah menggunakan teknologi. Di era sekarang ini para remaja banyak menggunakan media sosial maka berdakwah dengan melibatkan teknologi sudah menjadi pilihan yang tepat untuk berdakwah dikalangan remaja,jika kita melihat di sosial media sudah banyak akun yang membuat konten-konten dakwah yang menarik minat remaja, baik itu karena visualnya yang menarik atau dari audio yang sangat merdu untuk didengarkan dengan hal itu maka remaja jadi mencoba mencari tahu lebih dalam mengenai ajaran islam.

e. Metode Dakwah Melalui Sarana Olah Raga dan Seni 
Olah Raga dan Seni merupakan 2 bidang yang banyak diminati dikalangan remaja, hal ini juga menjadi metode yang tepat dalam berdakwah dikalangan remaja, salah satu olahraga yang disunnahkan itu memanah, dengan berolah raga memanah kita juga bisa sambil menyampaikan hal kebaikan berkaitan dengan islam, dan jika dalam seni kita dapat melihat yang saat ini sudah banyak lagu lagu yang berbau islami yang melantun baik itu di televisi, radio bahkan platform media sosial. 


\section{Simpulan}

Dalam perkembangan remaja ini bukan hanya fisik yang berubah tapi juga biologis, salah satu perkembangan pada remaja itu semangat yang tinggi maka dari itu remaja akan cenderung lebih mudah untuk dipengaruhi, jadi peniru dan ingin mendapatkan perhatian yang lebih dengan bertingkah baik itu positif ataupun negatif, peran dakwah dalam mengatasi kenakalan remaja itu dengan melalui beberapa metodependekatan yang dianggap sesuai dengan remaja masa kini sehingga akan lebih mudah untuk diterima oleh remaja , misalnya metode tanya jawab, metode diskusi, dakwah dengan contoh dan keteladanan, metode dakwah dengan sarana teknologi, dan yang terakhir metode dakh melalui sarana olahraga dan seni. Dengan melakukan metode seperti itu maka da'i dan remaja akan terasa semakin dekat dan akan lebih mudah untuk berdiskusi tentang keagamaan. 


\section{DAFTAR PUSTAKA}

Early Maghfiroh Innayati, Hubungan Antara Pengasuhan Islami Dengan Identitas Diri Pada Remaja Di Kota Yogyakarta

Prawira Yudha Yuwono, 2012, Peranan Metode Dakwah Dalam Mengatasi Problematika Remaja Di Kelurahan Procot Kecamatan Slawi Kabupaten Tegal, Skripsi, Institutagama Islam Negeri Syekh Nurjati Cirebon Sopian, 2017, Peran Dakwah Dalam Meminimalisir Kenakalan Remaja Di Desa Aeng Batu-Batu Kecamatan Galesong Utara Kabupaten Takalar, UIN Alauddin Makassar Sitti Muthmainnah, Peran Dakwah Dalam Mengatasi Konflik-Konflik Sosial Masa Kini 